\title{
LEITURA E(M) RUÍNAS DA MODERNIDADE: ALEGORIA, PERDA E FETICHISMO
}

\author{
Gilmário Guerreiro da Costa ${ }^{1}$ \\ "Tout pour moi devient allégorie" \\ Baudelaire, "O cisne"
}

\begin{abstract}
RESUMO
Este trabalho sustenta uma leitura crítica da modernidade a partir da articulação das noções de alegoria, perda e fetichismo. A alegoria moderna desvenda os mecanismos do império das mercadorias quando este reduz o universo sensível a um completo rebaixamento, tudo caindo num movimento implacavelmente horizontal de submissão dos objetos e dos homens ao sistema de trocas e consumo. A astúcia da fetichização da mercadoria reside em investir na perda para suplantar a perda, de que resulta obstar-nos a observação do devir. O olhar ofuscado pelas novidades do mercado não tem o descanso meditativo sobre aquilo que definha. Disso segue-se um paradoxo instrutivo: por um lado, testemunha-se a desvalorização do mundo profano, no qual não se observa sentido algum; por outro lado, dá-se mesmo a celebração desse mundo, visto que nele tudo é passível de significar qualquer coisa - inclusive, a própria superação desse estado de coisas. Não obstante, é precisamente essa possibilidade de imaginar um outro estado de coisa que resulta comprometida pela fetichização do cotidiano, tornado pretensamente um dado natural. Semelhante universo marcado pela segunda natureza e alienação teria sua encenação crítica no construto alegórico da arte moderna, em que a perda torna-se agora princípio compositivo, ensejando o espaço e o tempo do enfrentamento da reificação. É o que se buscará aqui demonstrar.
\end{abstract}

Palavras-chave: Alegoria, perda, fetichismo, fragmento, Walter Benjamin

\begin{abstract}
This essay outlines a critical reading of Modernity through an articulation of notions of allegory, loss, and fetishism. Modern allegory reveals the mechanisms of the merchandises' empire when they reduce the sensible universe to a complete depreciation, by which everything falls relentlessly into a horizontal movement of submitting men and things to the exchange and consumption system. The merchandise fetishism cunning lies in investing in loss so as to overcome loss, thus preventing us from the observation of the becoming. The eyes obfuscated by the market novelties do not have the meditative look at things which are about to languish. It follows an instructional paradox: on the one hand, we witness to the devaluation of the profane
\end{abstract}

\footnotetext{
${ }^{1}$ Pós-doutorando pela Cátedra Unesco-Archai (Universidade de Brasília) e pela Universidade de Coimbra. Professor e assessor do curso de filosofia da Universidade Católica de Brasília.
} 
world, in which one cannot see any sense; on the other hand, we may also see a kind of celebration of that world, because in it everything becomes likely to mean anything even the overcoming of this state of affairs. Nevertheless, it is precisely this ability to imagine other state of affairs that results jeopardised due to the everyday fetishism, turned allegedly into something natural. Such universe marked by second nature and alienation would have its critical scenery in the allegory construct of the modern art, in which loss now becomes a paradoxical compositional principle, allowing the space and time of reification's confrontation. This is what we will try to demonstrate.

Key-words: Allegory. Loss. Fetishism. Fragment. Walter Benjamin.

\section{Introdução}

Ciente das dificuldades que uma definição de arte impõe, Schelling sugere que Ihe delimitemos o lugar ocupado no universo, assim superando a possível estreiteza de uma definição: "Construir a arte significa determinar sua localização no universo. A determinação desse lugar é a única definição que dela existe." ${ }^{2}$ O filósofo alemão bem sustenta o liame entre arte e mundo, o que o seu idealismo poderia equivocadamente nos levar a julgar esquecido. Entretanto, do propósito, à realização, vai grande distância. Determinar a localização da arte no universo, se por si só é uma empresa cheia de obstáculos, posto que instigante, torna-se então hiperbólica na modernidade. Qual o lugar da arte na modernidade? Em grande medida, ela parece não ter lugar.

Numa descrição sombria, algo frankfurtiana, a arte não tem lugar pois se tornou mercadoria. Ocupa o lugar ao preço de renunciar a si mesma, deixando de ser arte. Um diagnóstico menos alarmista, mas nem por isso ingênuo, veria um potencial revolucionário, ou pelo menos crítico, em todo esse movimento, na medida em que a circulação ubíqua proveria condições de mais fácil acesso às obras de arte. Outras possibilidades poderiam ser mencionadas, como a que veria no gesto negativo e crítico de algumas experiências vanguardistas a recusa a ocupar um lugar determinado, destinando-a a uma marginalidade premeditada.

$\mathrm{Na}$ maior parte dos casos, a arte moderna aparece descrita como sem-lugar, cabendo indagar o que a conduziu a semelhante impasse, a tornar-se utópica por excelência. Acresce a isso a visão alegórica que a embala, afeita a não ter lugar, a

\footnotetext{
2 SCHELLING, F. W. J. Filosofia da arte. Trad. Márcio Suzuki. São Paulo: Edusp, 2001. (Clássicos). P.
} 37. 
"dizer o outro" (allegoria). Em tudo isso, figura de modo privilegiado a perda como seu princípio construtivo.

Essas são algumas questões que Benjamin encontra no cerne da poesia de Baudelaire. Refuta tratar-se de um ideólogo da arte pela arte, e o lê como tecedor de uma profunda concepção crítica de mundo. A poesia baudelairiana articula a cidade com uma espécie de teoria da modernidade, para as quais concorre um acento dado à transitoriedade e à morte. São elementos afins à visão alegórica desse poeta francês.

Baudelaire nota como o mundo regido pela mercadoria esparrama a transitoriedade e a morte, a desvalorização do mundo sensível. Compartilha com os poetas barrocos a ubiqüidade da perda de um remetimento seguro de sentido. Disso segue-se um paradoxo instrutivo: por um lado, neles vemos a desvalorização do mundo profano, no qual não se observa sentido algum; por outro lado, dá-se mesmo a celebração desse mundo, visto que nele tudo é passível de significar qualquer coisa.

A par com o afã infatigável pelo novo, segue o ritmo da produção capitalista inventando novidades transformadas em mercadorias, já "nascidas" sob o signo do transitório, do envelhecido. Tal ciclo conduz a um complexo processo de desvalorização dos objetos e dos seres, afim ao resultado da figuração alegórica. Perdemos assim a imediaticidade dos objetos, bem como das palavras. Ou, de modo mais implacável, desiludimo-nos de já haver possuído semelhante imediaticidade, o caminho de uma origem do sentido que nos apresentaria tais objetos e palavras.

A modernidade investe na perda para suplantar a perda. As ruínas incessantes das mercadorias visam a um incremento infrene do consumo, e que resulta em obstar a observação do devir. Os olhos ofuscados pelas novidades do mercado não têm o descanso meditativo sobre aquilo que definha. A tristeza e solidão são substituídos pela histeria e isolamento. Como resultado, a perda, suspensão provisória do tempo, que revela ainda mais intensamente a materialidade do tempo, finda por ser eclipsada pelo tumulto de uma vida que não acha ocasião de auto-examinar-se.

É um processo complexo, incrementado pelo elemento mítico do desejo, que ao tornar-se mercadoria, aspira ao eterno: "Mas no processo de se tornar mercadorias, as 
imagens de desejo se congelam em fetiches; o mítico aspira à eternidade." ${ }^{33} \mathrm{O}$ ritmo da mercadoria, quando pretexta roçar o eterno, num hausto mágico, petrifica a história, roubando-Ihe todo movimento. Ocorre, no entanto, uma inversão dialética. A mercadoria move-se no ritmo do novo que the inspira o passo. A contraparte da pulsão pelo novo é o envelhecimento rápido da mercadoria. Se antes a mercadoria, por ato de enfeitiçamento, paralisava o devir histórico, agora, em virtude da transitoriedade a que sucumbe pelas exigências de novidade, deixa entrever em seus traços os vincos temporais da mudança:

Mas essa natureza fetichizada também é transitória. A outra face da repetição infernal do "novo" na cultura de massa é a mortificação daquilo que já não é novidade. Os deuses se tornam antiquados, seus ídolos se desintegram, seus lugares de culto — as próprias passagens — entram em decadência. ${ }^{4}$

A discussão acerca da mercadoria conduz ao cerne do problema da segunda natureza. Trata-se de um conceito hegeliano referido ao conjunto de objetivações do espírito humano que se fossilizam, apresentando um arremedo de independência. Adorno nota que Benjamin serviu-se desse conceito como instrumento crítico para pensar a alienação no mundo moderno, articulando-o com o conceito marxista de fetichismo da mercadoria: "Em Benjamin, ganha uma posição-chave o conceito hegeliano de segunda natureza enquanto objetivação de relações humanas alienadas de si mesmas, bem como a categoria marxista do fetichismo da mercadoria." ${ }^{5}$ Semelhante aparato crítico abebera-se tanto de G. W. F. Hegel e Karl Marx quanto de Georg Lukács. Deve-se a este último a utilização do conceito hegeliano na compreensão do romance, num primeiro momento, e em seguida no intuito da acercarse do fetichismo da mercadoria, investigado como uma sorte de segunda natureza. Ambos os traços se observam na articulação benjaminiana entre alegoria e mercadoria, e conduzem a um diagnóstico semelhante: a modernidade frustrou as suas promessas de emancipação, deixando um esparrame de morte e alienação, exibidas no

${ }^{3}$ BUCK-MORSS, Susan. Dialética do olhar: Walter Benjamin e o projeto das Passagens. Trad. Ana Luiza Andrade. Belo Horizonte: Editora UFMG; Chapecó: Editora Universitária Argos, 2002. P. 200

4 Idem, p. 200.

5 ADORNO, Theodor. "Caracterização de Walter Benjamin". In Prismas: crítica cultural e sociedade. Trad. Augustin Wernet e Jorge Mattos Brito de Almeida. São Paulo: Ática, 1998. P. 228 
esvaziamento inclemente da interioridade do sujeito. A alegoria lhe fará a denúncia, e em seus meandros mais silenciosos, dará a ouvir algum sopro utópico.

\section{O perfil da segunda natureza: alegoria, morte e alienação}

A teoria do romance, de Lukács, foi publicado em 1916 (em húngaro, a edição alemã é de 1920). Ensaio de notável envergadura, ocupa lugar destacado no estudo do romance, que contrapõe à epopéia clássica, nele vendo o status de um gênero imerso numa época de alienação e perda da totalidade da vida, devido à dissolução das comunidades orgânicas tradicionais ${ }^{6}$, tema adiante retomado por Benjamin no ensaio "O narrador". A contraposição entre epopéia e romance servir-se-á, por força do abandono sofrido pelo homem moderno, do conceito de segunda natureza como reflexo e refração do herói romanesco, em sua luta contra estruturas sociais frias e reificadas.

A primeira natureza, na definição kantiana de Lukács, é "a natureza como conforme a leis para o puro conhecimento."7 Vai nessa afirmação entendimento algo reificado do que seja a natureza como objeto para o nosso conhecimento, disponível ao aparato dominador dos nossos conceitos. Com ela o filósofo húngaro não avança com relação à ciência burguesa que em muitos momentos critica. Está mesmo em consonância com o espírito dos tempos modernos e das exigências do capitalismo.

A novidade e mesmo a contribuição mais alvissareira está na definição de segunda natureza, reveladora do caráter cristalizado de que se revestem por vezes os produtos do espírito humano, cujo conhecimento revela pressupostos mais difíceis de se deslindar do que o observado na primeira natureza; afinal, é o reino da "cristalização de interioridades" ${ }^{\text {. }}$. Esse conceito faz recair no que haveria de alienado e morto no mundo ${ }^{9}$.

A dominância da alienação e do aspecto reificado de nossa relação com o mundo serve de empeço ao alcance de uma compreensão da totalidade da existência. É nesse sentido que se encaminham as reflexões lukácsianas acerca do romance, a epopéia da nossa época, que entrelaça a vivência da perda da totalidade. Assim, sob o

\footnotetext{
${ }^{6}$ LUKÁCS, Georg. A teoria do romance: um ensaio histórico-filosófico sobre as formas da grande épica. Trad. José Marcos Mariani de Macedo. São Paulo: Duas Cidades/Ed. 34, 2000. (Coleção Espírito Crítico). P. 68.

7 Idem, p. 65.

8 Idem, p. 65.
} 
signo da perda é que logramos modo privilegiado de compreensão da modernidade: "O romance é a epopéia de uma era para a qual a totalidade extensiva da vida não é mais dada de modo evidente, para a qual a imanência do sentido à vida tornou-se problemática, mas que ainda assim tem por intenção a totalidade..10

A perda que serve de esteio ao romance também esclarece a cristalização de sentido definida como segunda natureza. Tendo perdido a legítima visada na totalidade da vida, substitutos espúrios não tardam em surgir, deles sendo difícil a confrontação pelo nível de alienação em que estamos. A segunda natureza é revelada no romance como um processo implacável de dominação e rigidez, esvaziado de toda vida:

\begin{abstract}
Essa natureza não é muda, manifesta e alheia aos sentidos como a primeira: é um complexo de sentido petrificado que se tornou estranho, já de todo incapaz de despertar a interioridade; é um ossuário de interioridades putrefatas, e por isso só seria reanimada - se tal fosse possível - pelo ato metafísico de uma ressurreição do anímico que ela, em sua existência anterior ou de dever-ser, criou ou preservou, mas jamais seria reavivada por uma outra interioridade. ${ }^{11}$
\end{abstract}

São imagens que revelam o desconsolo da vida moderna, com o seu museu de interioridades mortas e vazias. As criações humanas segregaram-se e assumiram dura cerviz no controle dos homens. O mundo que antes, conquanto tão vasto, era uma lar para herói épico, tornou-se em cárcere: "o mundo circundante criado para os homens por si mesmos não é mais o lar paterno, mas um cárcere."12

Esse quadro de ubiqüidade da morte soará sugestivo a Benjamin, seja na alegoria barroca, seja na moderna, pois a operação alegórica terá especial habilidade em atentar para o caráter morto e desiludido no palco da história. A implicação entre significação e morte, na alegoria barroca, também movimenta a alegoria moderna, mas agora o seu exercício implica o esvaziamento de todo significado num mundo cujo valor vem das mercadorias, que imprime inversão dialética perversa, quando torna em objetos os sujeitos que as produziram. A alegoria, por fazer da perda seu meio compositivo, em suas malhas permite ver e ouvir um universo de perdas sob o brilho fugaz das mercadorias. Isso ainda mais se esclarece com o conceito de fetichismo da mercadoria.

\footnotetext{
9 Conferir Buck-Morss, op. cit., p. 201

${ }^{10}$ LUKÁCS, A teoria do romance, p. 55

${ }^{11}$ Idem, p. 64
} 


\section{Alegoria, fetichismo da mercadoria e ocultamento da perda}

O fetichismo da mercadoria ocupa lugar de relevo na análise que Marx fez da economia capitalista. Refere-se ao ocultamento da origem do valor da mercadoria, cujo arremate dá-se com a substituição da sua materialidade por um valor abstrato. Ao apagamento dos traços genealógicos segue-se a naturalização do valor de troca, que sugere ser a mercadoria portadora de um sentido intrínseco, alheio às trocas e ao trabalho social. Numa época pautada pela onipresença de relações reificadas e objetos enfeitiçados, o fetiche da mercadoria parece operar com uma promessa de acesso imediato e evidente às coisas.

No tentame de esclarecer o "mistério" da mercadoria, Marx se serve de uma analogia com a religião, em termos semelhantes ao que fizera no exame da ideologia, a saber, os produtos da mente humana (as idéias religiosas) e do trabalho (mercadorias) alcançam autonomia com se tivessem vida própria ${ }^{13}$. Dessa maneira, as mercadorias desfazem os traços de sua gênese:

Aqui [na religião], os produtos do cérebro humano parecem dotados de vida própria, figuras autônomas, que mantêm relações entre si e com os homens. Assim, no mundo das mercadorias, acontece com os produtos da mão humana. Isso eu chamo o fetichismo que adere aos produtos do trabalho, tão logo são produzidos como mercadorias, e que, por isso, é inseparável da produção da mercadoria. $^{14}$

Tal metamorfose é possibilitada pela alienação e reificação do trabalho humano. Perdendo a compreensão da teia complexa que o trabalho ajuda a tecer, perdemos as condições para acompanhar e denunciar o salto místico da mercadoria, e isso porque a essa altura as próprias relações sociais acham-se sobremodo reificadas. ${ }^{15}$

\footnotetext{
12 Idem, p. 64-5

${ }^{13}$ Assim como na religião o homem abdicaria da responsabilidade de agir em função de uma Vontade Soberana que legislaria o cósmos, o capitalista afirma não deter qualquer poder sobre as mercadorias. O criador não reconhece a criatura: "Os produtos de sua cabeça acabaram por se impor à sua própria cabeça”. (MARX e ENGELS, 1999, p. 17). O que Marx então escreve acerca da ideologia, materializase no enfeitiçamento dos objetos na economia capitalista.

${ }^{14}$ MARX, Karl. O capital: crítica da economia política. Trad. Regis Barbosa e Flávio Kothe. São Paulo: Abril Cultural, 1983. Vol. 1. P. 71

${ }^{15}$ Idem, p. 71. Conferir também Octavio lanni "Em essência, o capitalismo é um sistema de mercantilização universal; e de produção de mais-valia. Mercantiliza as relações, as pessoas e as coisas." (1988, p. 18)
} 
Diferentemente, Marx insiste em que os padrões de valor não existem sub speciae aeternitas: são humanos, demasiado humanos. A sua insubmissão ao controle é uma ficção que serve tão somente à estabilidade do sistema, cuja racionalidade não é expediente além do bem e do mal, além da história e dos interesses humanos. Constroem-se em meio aos mais dramáticos embates sociais. Não é uma estrutura transcendental, mas contingente, histórica.

Ao olhar de Marx, a mercadoria surpreende um quadro mais complexo do que se suspeita, o que inclui traços metafísicos e teológicos: "vê-se que ela é uma coisa muito complicada, cheia de sutileza metafísica e manhas teológicas." ${ }^{16}$

Não há dificuldade no entendimento do valor de uso da mercadoria, que advém da utilidade do produto criado bem como do esforço humano na transformação do mundo pelo trabalho. Mas os problemas emergem quando buscamos compreender o valor de troca da mercadoria, espécie de metamorfose metafísica dos objetos surgidos da ação social do trabalho humano. Marx oferece o exemplo da mesa. Seu valor de uso vem da finalidade a que se destina, bem com do esforço humano na transformação da forma madeira. Retirada desse contexto, no entanto, ela se torna mercadoria, e sorve surpreendente hausto metafísico. Em termos benjaminianos, é auratizada. Marx descreve ironicamente semelhante processo:

\begin{abstract}
Mas logo que ela aparece como mercadoria, ela se transforma numa coisa fisicamente metafísica. Além de se pôr com os pés no chão, ela se põe sobre a cabeça perante todas as outras mercadorias e desenvolve de sua cabeça de madeira cismas muito mais estranhas do que se ela começasse a dançar por sua própria iniciativa. ${ }^{17}$
\end{abstract}

Esquecido do esforço social responsável pela origem das mercadorias, o fetichismo opera com o intento de revesti-los de um valor supostamente intrínseco. Outra sorte de sutileza metafísica, que retira objetos da imanência social, pouco atrativa, e lhes concede uma transcendência envolta em paradoxos, porque forjada por homens contra si mesmos. O "gênio" da alienação: a admiração de produtos por nós criados justamente por nos parecerem autônomos, independentes de nós mesmos: "como si estos últimos [os objetos] tuvieran cualidades misteriosas que les hicieran

\footnotetext{
${ }^{16}$ Idem, p. 70

17 Idem, p. 70
} 
valiosas por sí mismos, o como si el valor fuera una propiedad natural y física de las cosas." ${ }^{18}$ A alienação observada no fetichismo da mercadoria articula-se em grande medida com as outras formas da alienação: a autonomia das instituições políticas, a erguer-se falsamente além dos embates sociais, e que muitas vezes torna-se instrumento opressor; as fantasias religiosas, cuja suposta existência confirma uma autonomia com relação à mente humana (lbidem).

Passo crucial nessa direção será dado com a criação do dinheiro. Da passagem do valor de uso ao de troca ocorre uma cisão, que faz perder a compreensão do caráter social do trabalho realizado na confecção do produto. A equiparação das mercadorias à forma dinheiro abisma-nos ainda mais na ignorância do processo, deixando-as exibirem o lustre de uma aparição a-histórica. Tudo se passa como obedecendo a um fluxo natural $^{19}$. Destarte, compreende-se que seja o fetichismo da mercadoria um fenômeno intimamente ligado à criação do dinheiro: "O fenômeno do fetichismo da mercadoria relaciona-se estreitamente com a criação do dinheiro." ${ }^{20} \mathrm{~A}$ troca de mercadorias exige uma mercadoria que sirva como referência a todas as outras trocas. Esta será o dinheiro, que se torna independente, causando espanto, pois seria um instrumento para intermediar trocas entre objetos, e eis que assume posição independente fora dos mesmos objetos.

O desenvolvimento da modernidade revela um processo imerso em contradições, desde o seu sonho de liberdade e autonomia, até o sepultamento dessas expectativas com o triunfo do capitalismo, em especial com as relações ubíquas do fetichismo da mercadoria. É precisamente a tão decantada liberdade o que se encontra em risco: "Quando descreve a sociedade capitalista, Marx observa constantemente que tudo nela se encontra sob "ilusões de época", tudo nela é dominado pelo "fetichismo" e não é, portanto, livre - exceto, é claro, o grupo revolucionário "plenamente consciente"."21 Não deixa de ser algo irônico que Marx e Weber chegassem à mesma conclusão acerca da modernidade burguesa, ainda que tenham se posicionado diferentemente

\footnotetext{
${ }^{18}$ KOLAKOWSKI, Leszek. Las principales corrientes del marxismo: I. los fundadores. Trad. Jorge Vigil. Madrid: Alianza Editorial, 1978. P. 278

${ }^{19}$ Marx, op. cit., p. 73

${ }^{20}$ ROSDOLSKY, Roman. Gênese e estrutura de O capital de Karl Marx. Trad. César Benjamin. Rio de Janeiro: EDUERJ/Contraponto, 2001. P. 115
} 
acerca do seu valor: trata-se de período marcado pela perda de liberdade, envidando desmedidos esforços para compor texto inconsútil com o fito de recalcar uma suprema desolação.

Lukács insere-se nesse debate mediante a articulação do fetichismo da mercadoria com o conceito de segunda natureza. Tal projeto atravessa a seção mais influente de História e consciência de classes, que trata do problema da reificação.

Como foi exposto acima, o fetichismo oferta autonomia dissimulada às mercadorias. O processo se dissemina, e para acompanhá-lo Lukács serve-se do conceito de reificação (Verdinglichung, que segundo Merquior ${ }^{22}$ é um conceito de Georg Simmel). Ambos os conceitos possibilitam mais clareza na análise do fenômeno da alienação, quando os objetos produzidos pelos homens e a própria história deles se liberta, como por mágica, forjando uma segunda natureza.

A estrutura da mercadoria é o protótipo, segundo Lukács, das formas de objetividade e subjetividade da sociedade burguesa. A essência da estrutura da mercadoria é a reificação das relações entre os homens, sendo assim necessário que a tomemos como categoria universal em nossa época ${ }^{23}$. Seria desse modo que se conseguiria visualizar a "segunda natureza" a que nos encontramos condicionados (Ibidem). Semelhante processo de reificação vai num crescendo tanto na racionalização do trabalho, quando vai desaparecendo qualquer interesse pelas propriedades qualitativas e humanas do trabalhador, quanto na fragmentação da sua atividade, submetida a um quadro progressivamente limitado ${ }^{24}$.

Todas as dimensões e contornos da vida social estariam viciados pelas demandas reificadoras da mercadoria, texto todo-englobante e preciso que habilmente evita que algo the escape ao domínio. Rasgar semelhante texto não raro é uma pretensão que cai na armadilha de ainda mais embaraçar-se em suas malhas: "Lukács insiste no fato de que, na sociedade capitalista, nenhuma forma de relação entre os homens escapa à submissão, à forma reificada da objetividade, que transforma cada

${ }^{21}$ BERMANN, Marshall. Aventuras no marxismo. Trad. Sonia Moreira. São Paulo: Companhia das Letras, 2001. P. 53

${ }^{22}$ MERQUIOR, José Guilherme. O marxismo ocidental. Trad. Raul de Sá Barbosa. Rio de Janeiro: Nova Fronteira, 1987. P. 111

${ }^{23}$ LUKÁCS, Georg. História e consciência de classes: estudos sobre a dialética marxista. Trad. Rodnei Nascimento. São Paulo, Martins Fontes, 2003. P. 198. 
característica ou qualidade humana em "coisa", ou então em mercadoria."25 O processo de desumanização a que nos submete procede, mormente no caso do proletariado, a um isolamento crescente por força do rompimento dos laços típicos das comunidades orgânicas, cuja existência está ameaçada pelas novas exigências traçadas pela produção capitalista. Lukács assim acentua as limitações impostas a homens que somente podem oferecer uma força de trabalho alienado e exposto como mercadoria. $\mathrm{O}$ trabalho, de que esperaríamos a revelação da essência humana, apenas coisifica e esvazia ${ }^{26}$.

Conquanto movido por um projeto fundado num compromisso com a totalidade, tais estudos lukacsianos serviram de esteio para o percurso benjaminiano. Ainda que o interesse de Benjamin tenha se guiado antes pela fragmentação que pela totalidade, pareceu-Ihe crucial a visada na vida que jaz morta na natureza como reveladora do que a história desenvolveu ${ }^{27}$, que se revelava sob a rubrica da segunda natureza em História e consciência de classes. $O$ autor de $A$ origem do drama barroco alemão conduzirá tais questões para um exercício de radicalização fragmentária, disso emergindo uma concepção afeita à transitoriedade. Experiência a uma só vez textual e temporal, estruturada pela perda. Esse seria o cerne do itinerário que ele viu no movimento alegórico da literatura moderna.

\section{A alegoria moderna e Baudelaire: o esfacelamento da bela aparência}

A estrutura da literatura moderna, segundo Benjamin, confere função emblemática à temporalidade, assumindo para si a tarefa de reflexão acerca da modernidade, cuja transitoriedade desdobra-se insaciavelmente. Tal movimento é visível nas tensões e oposições da construção poética de Baudelaire.

O vetor crítico da poesia baudelairiana dirige-se ao caráter devorador do tempo moderno, mas também atinge os aspectos alienados do trabalho na sociedade capitalista e a racionalização do mundo da vida submetido ao controle impassível dos

\footnotetext{
${ }^{24}$ Idem, p. 198

${ }^{25}$ LÖWY, Michel. Romantismo e messianismo: ensaios sobre Lukács e Walter Benjamin. Trad. Myrian Veras Baptista e Magdalena Pizante Baptista. São Paulo, Perspectiva/Edusp, 1990. P. 76.

${ }^{26}$ LUKÁCS, História e consciência de classes, p. 205-6

27 BUCK-MORSS, op. cit., p. 201.
} 
relógios. Ao dizer tal impulso devorador, os versos baudelairianos são uma frágil aposta de nos remeter aos domínios do eterno. Ao lamentar a perda, os poemas assumem o lugar de substitutos da perda, presumem triunfar sobre o descaso do tempo moderno, uma aposta que deixa a impressão de um fracasso apenas adiado.

Essas questões são examinadas em diversos textos benjaminianos dedicados à poesia de Baudelaire. Entre eles, pode-se destacar "Paris, capital do século XIX" e "Parque central".

"Paris, capital do século XIX" inicia referindo-se às galerias parisienses, estabelecimentos de comércio voltados para a venda de mercadorias de luxo. Espécie de paraíso profano da mercadoria: "As galerias são centros comerciais de mercadorias de luxo. Em sua decoração, a arte põe-se a serviço do comerciante."28

Benjamin procura explicar as condições econômicas para o desenvolvimento das galerias. Destaca o desenvolvimento do comércio têxtil: "A primeira condição para o seu florescimento é a alta do comércio têxtil."29 Também cruciais são os ensaios de construções com ferro: "A segunda condição para o surgimento das galerias é dada pelos primórdios da construção com ferro." ${ }^{30}$ Isso traz implicações importantes para a arquitetura: o uso incipiente de material artificial: "Com o ferro aparece, pela primeira vez na história da arquitetura, um material artificial. A isto subjaz uma evolução cujo ritmo se acelera no decorrer do século."31

Em seguida, ele examina as exposições universais, eventos que concorrem muito favoravelmente para a ubiqüidade das metamorfoses comuns ao fetichismo da mercadoria, cujo poder transfigurador seria assim catalisado. Nelas é notável a cisão entre valor de troca e o de uso:

As exposições universais transfiguram o valor de troca das mercadorias. Criam uma moldura em que o valor de uso da mercadoria passa para segundo plano. Inauguram uma fantasmagoria a que o homem se entrega para se distrair. A indústria de diversões facilita isso, elevando-o ao nível da mercadoria. O sujeito se entrega às suas manipulações, desfrutando a sua própria alienação e a dos outros. $^{32}$

\footnotetext{
${ }^{28}$ BENJAMIN, Walter. "Paris, capital do século XIX". In Sociologia. Trad. Flávio Kothe. São Paulo, Ática, 1991. (Coleção Grandes Cientistas Sociais). P. 31.

${ }^{29}$ Idem, p. 30.

${ }^{30}$ Idem, p. 31.

${ }^{31}$ Idem, p. 31.

${ }^{32}$ Idem, p. 35-6.
} 
O império da mercadoria dissemina sombras e fantasmas por todos os lados. Nada há que escape a essa caráter fluido da realidade. Entretanto, longe de significar emancipação e abertura de espaços criativos, a dissolução da realidade implica mesmo o maior enredamento em relações alienadas. Mundo desumanizado e ilusão na suposta univocidade das exteriorizações do espírito aprofundam-se e espalham-se. Nas exposições, a indústria de diversões torna o próprio homem mercadoria.

Benjamin, num lance de ousadia, que permite divisar o cerne das relações entre alegoria e mercadoria, articula o fetichismo e o inorgânico:

\begin{abstract}
A moda prescreve o ritual segundo o qual o fetiche mercadoria pretende ser venerado. Grandville estende tal pretensão aos objetos de uso cotidiano e inclusive ao cosmos. Ao levá-los até os seus extremos descobre a sua natureza. Ela consiste na contraposição ao orgânico. Relaciona o corpo vivo ao mundo inorgânico. Percebe no ser vivo os direitos do cadáver. Seu nervo vital é o fetichismo, subjacente ao sex-appeal do inorgânico. O culto à mercadoria coloca-o a seu serviço. ${ }^{33}$
\end{abstract}

O fetichismo transforma em fantasma o mundo circundante, ou melhor, torna ausente de mundo a realidade. Posto que a descartabilidade the sirva de divisa, a mercadoria projeta a antropomorfização dos objetos, nos quais recairiam imagens cujo desejo pareceria como que despertado pela intenção sedutora de um ser dotado de vontade. Mas a mercadoria também operaria o inverso, a objetivação dos homens, ao reificar homens e relações que estabelecem entre si. É com fina ironia que Benjamin refere-se ao "sex-appeal do inorgânico". A fantasmagoria moderna teria sua tradução no suposto caráter sedutor da mercadoria. Tudo se passa como se ela nos inclinasse ao seu talante.

O contraste da atitude do colecionador e do flâneur, com a massa dos consumidores, permite um melhor entendimento dessas reflexões. A atividade do colecionador libera as coisas da ditadura da utilidade e da mercadoria. Desfaz o feitiço da mercadoria, ao conceder às coisas valor afetivo. Corresponde a um ato de desafio da desumanização pelo impulso amoroso. Há nessa atividade aceno de esperança e redenção. Recende a utopia:

\footnotetext{
${ }^{33}$ Idem, p. 36.
} 
O interior da residência é o refúgio da arte. O colecionador é o verdadeiro habitante desse interior. Assume o papel de transfigurador das coisas. RecaiIhe a tarefa da Sísifo de, pela sua posse, retirar das coisas o seu caráter de mercadorias. No lugar do valor de uso, empresta-lhe tão-somente um valor afetivo. O colecionador sonha não só estar num mundo longínquo ou pretérito, mas também num mundo melhor em que os homens estejam tão despojados daquilo que necessitam quanto no cotidiano, estando as coisas, contudo, liberadas da obrigação de serem úteis. ${ }^{34}$

O ofício do colecionador trai perspectivas utópicas na medida em que subverte o domínio do fetichismo da mercadoria e encena outra ordem de relações dos homens com os objetos. O movimento que imprime desfaria o feitiço da mercadoria ao fazê-la perder toda a autonomia, fazendo-a servir ao interesse afetivo. Nesse sentido, torna-se indisponível às trocas comerciais. O gesto de descontextualização do colecionador imprimiu-Ihe a violência amorosa suficiente para desdizer qualquer ressaibo aurático ${ }^{35}$.

É no andar do flâneur que Benjamin encontrará sugestões para pensar a retomada de interesse pela alegoria em Baudelaire (Ibidem, p. 38-9). O seu olhar alegórico é o olhar do estranhamento, próximo do vivenciado pelo flâneur nas caminhadas livres pela cidade. É o reconhecimento de não pertença a qualquer grupo ou cidade. Há nele algo de errante, espécie de memória de uma humanidade livre, perdida por entre os destroços da vida burguesa. O olhar do flâneur, ainda livre das injunções da cidade e da classe burguesa, encontra-se no ritmo dos versos baudelairianos.

A cidade revela caráter estranho ao flâneur porque o seu andar irmana-se do ardor do colecionador: ambos descontextualizam objetos (colecionador) e relações (flâneur), em movimento cujo caráter outrora familiar da mercadoria, dada a alienação que a envolve e protege, agora se desfigura e revela o absurdo que encobre a fantasmagoria dos objetos - o monismo espúrio da mercadoria, com a síntese bufa de espírito e matéria. O flâneur pode mesmo divertir-se com a situação estranha que vive: emblema da estranheza recalcada desse mundo de mercadoria. Se o flâneur parece

\footnotetext{
34 Idem, p. 38.

${ }^{35} \mathrm{O}$ "banho estético" de algumas mercadorias não tem deixado lá tão incólume assim o colecionador. Ao que tudo indica, as suntuosas "caixas de colecionadores" (livros, dvd, cd etc.) parecem em vias de tomar essa atividade ao seu serviço. $O$ ato de colecionar não é infenso à magia do mercado. Sem que sejamos necessariamente fatalistas, pode-se presumir ser o ofício de descontextualização imprimido pelo colecionador algo perfeitamente previsto pelo contexto da mercadoria.
} 
ridículo, é porque encena ardilosamente a marginalidade de tudo o que destoa dos reclamos vigentes de utilidade.

A estranheza nutrida pela descontextualização dos objetos do colecionador, e vivenciada pelo olhar melancólico do flâneur instruem os versos baudelairianos numa sensibilidade diante da perda de um mundo dotado de sentido, vivido por sujeitos de interioridade igualmente esvaziada. Baudelaire lamenta-se a perda de um outro modo de viver.Pode-se suspeitar que esse outro tenha mais de projeção de desejo que densidade histórica. Mas o poeta francês quer conduzir o processo adiante, e com a força da violência alegórica, ainda mais rebaixar esse mundo já tão afetado pela operação redutora da mercadoria. Ao fazê-lo, Baudelaire, longe de imergir num pathos niilista, está fiando estranha sorte de expectativa de mudança para uma outra humanidade.

Ele recusará assim o menor esboço de impor a transfiguração da realidade pela bela aparência, tampouco se ilude com movimento que conduziria ao desvelamento do Ideal. Mesmo quando a idealidade aparece nos versos, ela está vazia, sem componente que avalize o transe do espírito. Antes, o poeta francês demonstrará apreço por aquilo que declina, que se estilhaça. Servirá a esse propósito o spleen, em gesto próximo ao da fragmentação alegórica, e que despedaça o ideal. Primeiro caso de "transcendência vazia" ${ }^{36}$, que a lírica de Mallarmé haveria de conduzir ao seu acabamento: "Com o spleen ele deixa o ideal em pedaços ("Spleen et Idéal")."37

Semelhante concepção postula a Queda sem promessa messiânica, mal sem contraparte redentora. A transcendência vazia da lírica, expondo os estertores do Inferno moderno. O soneto "Horror simpático", de As flores do mal (LXXXII), concentra a força dessa imaginação alegórica, no dilaceramento que imprime ao mundo. No poema, vemos encenado o diálogo do poeta com um libertino, a quem indaga sobre o que deita os seus pensamentos. Especialmente as duas últimas estrofes bem concentram a força da transgressão da bela aparência, com forte impacto com a temporalidade que se derrama em seus versos, nos quais a perda "sustenta" a estruturação:

\footnotetext{
${ }^{36} \mathrm{O}$ termo é de Hugo Friedrich. Usa-o preferencialmente quando se refere a Rimbaud e Mallarmé. Mas vê já em Baudelaire esboçada a "idealidade vazia": nele "emerge uma característica de conteúdo da lírica posterior, que chamaremos de idealidade vazia." (FRIEDRICH, 1978, p. 45)

37 BENJAMIN, "Paris, capital do século XIX", p. 39.
} 


\begin{abstract}
Cieux déchirés comme des grèves,
En vous se mire mon orgueil;

Vos vastes nuages en deuil

Sont les corbillards de mes rêves,

Et vos lueurs sont le reflet

De l'Enfer où mon coeur se plaît. ${ }^{38}$
\end{abstract}

No plano geral, descemos do céu e vamos ao Inferno e deste, ao coração do libertino. $O$ céu servirá também internamente para os demais contrastes: nele o libertino espelha o próprio orgulho; a perda dos seus sonhos é desfiada no movimento em que das nuvens do céu figura uma lutuosa caravana; e a luminosidade frouxa do céu revela o Inferno em que o libertino acha contentamento. Alastra-se o plano sucessivo e a transitoriedade, revelando visão de mundo fragmentada e crítica. Os elementos da natureza, candidatos a símbolos abarcadores, decaem de uma posição privilegiada, e sucumbem ao plano alegórico que as conduz ao homem, num registro especular em que o Spleen e o Ideal fundam um oximoro do conflito, e não da reconciliação.

A rasgadura do Céu o faz despencar e desvelar um homem há muito fracassado. Cenário implacável de perda, em que os versos deitam a lamentá-la, mas ao fazê-lo de algum modo figuram como substitutos. Trata-se de evento paradoxal e incômodo, esse que conduz a encenar a perda com um texto que tanto a diz quanto a suplanta.

Algo dessa contradição interna diz muito da própria escrita literária, e faz da alegoria moderna, no processo de perda que a estrutura, lócus privilegiado de reflexão acerca da prática da escrita literária. Os oximoros assim impõem seu fardo incontornável: nosso êxito somente se esboça quando assumimos o fracasso da escrita em lidar com a perda, que a move. Um êxito no fracasso para contrapor-se ao falso êxito do triunfalismo da bela aparência. Além do mais, fala-nos o mestre da dissonância e da desfiguração moral: o libertino.

Em tudo isso a ambigüidade revela o máximo interesse para Benjamin. É uma espécie de dialética paralisada. Nela temos, num texto, por exemplo, a exibição de uma

\footnotetext{
${ }^{38}$ BAUDELAIRE, Charles. As flores do mal. Trad. Ivan Junqueira. Rio de Janeiro, Nova Fronteira, 1985. Edição bilíngue. P. 304.

Ivan Junqueira assim traduz os versos: "Céus destroçados e tristonhos, / De vós o meu orgulho é fruto; / Vossas grossas nuvens de luto / São os esquifes de meus sonhos, / E vosso espectro a imagem traz / Do Inferno que à minha alma apraz."BAUDELAIRE, 1985, p. 305. Em alguns momentos nos
} 
dialética fotografada que, no entanto, revela movimento negativo: não é a superação o que se paralisa, mas o conflito: "Ambigüidade é a imagem visível e aparente da dialética, a lei da dialética em estado de paralisação." ${ }^{39}$ Nela podemos ler em câmara lenta o processo de desfiguração a que a alegoria submete o texto literário, fragmentando-o e tornando a perda não o refugo, mas o princípio máximo da composição da escrita.

Outro trabalho benjaminiano igualmente importante no exame da alegoria moderna é "Parque central", um texto radicalmente fragmentário, no qual lemos algumas das mais instigantes intuições acerca do uso baudelairiano da alegoria. $O$ texto consegue ir aonde o poeta francês não pôde ir, ao desfigurar-se a si mesmo e o si mesmo, impondo-Ihe impulso de montagem caro às vanguardas do que o crítico alemão foi confesso admirador.

A alegoria procede a uma degradação do mundo sensível em nome de um princípio destrutivo. Benjamin refere-se à "força destrutiva da intenção alegórica" 40 . Semelhante intenção detém-se em fragmentos, impulsionada por um duplo movimento: o olhar descontextualiza objetos para melhor observá-los, ou mesmo experimentar novos olhares; também seriam os fragmentos o resultante do impulso destrutivo da intenção alegórica, movendo uma denúncia da falsa totalidade, espúria superação de toda perda. Ao fazê-lo, o que a intenção alegórica oferece é um abismo de perdas ainda maiores. Espécie de figura de ostentação de um triunfo na ruína e na dissolução.

Mas não se trata de movimento aniquilador. Os fragmentos então resultantes do penetrante olhar alegórico são de algum modo conservados, conquanto o sejam em nível radicalmente descontextualizado:

\footnotetext{
O que é atingido pela intenção alegórica passa a ser segregado do contexto da vida: é, ao mesmo tempo, destroçado e conservado. A alegoria se fixa nos fragmentos. Oferece a imagem da inquietação subitamente congelada. Ao impulso destrutivo de Baudelaire jamais interessa a eliminação daquilo que ele faz ruir. ${ }^{41}$
}

afastaremos desta tradução, com o intuito de melhor explicitar o jogo de desmontagem em que o poema se inscreve.

39 BENJAMIN, "Paris capital do século XIX", p. 39.

${ }^{40}$ BENJAMIN, "Parque central". In Sociologia. Trad. Flávio Kothe. São Paulo, Ática, 1991. (Coleção Grandes Cientistas Sociais). P. 127. Conferir também página 152, em que o autor menciona "a tendência destrutiva da alegoria".

${ }^{41}$ Idem, p. 131. 
Benjamin sugere a articulação entre a descontextualização dos objetos em Baudelaire (que atinge em cheio a cena das exposições de mercadorias) e a violência alegórica contra o orgânico. Totalidade (espúria) e segunda natureza (rígida, sem vida) são a uma só fez enfrentadas: "Arrancar as coisas de seu contexto habitual — o que é normal quanto às coisas no estágio de sua exposição - é um procedimento bem característico de Baudelaire. Relaciona-se com o aniquilamento."42

Entende-se, assim que a alegoria no poeta francês seja um instrumento com vistas à dessacralização e perda da aura: "A dessacralização e a perda da aura são fenômenos idênticos. Baudelaire coloca a seu serviço o artifício da alegoria."43 A alegoria baudelairiana, a exemplo da barroca, esforça-se por desfazer falsas harmonias. A novidade de Baudelaire, ou o que nele surpreende é a ira que impulsiona o seu procedimento, forçando passagem no mundo das mercadorias.

O cadáver, emblema que ocupa lugar importante na alegoria barroca, também revela pertinácia em Baudelaire. A diferença é que o poeta francês ousa vê-lo de dentro: "A alegoria barroca só vê o cadáver desde o lado de fora. Baudelaire também o vê desde dentro."44

Lukács notou como a segunda natureza revelava uma interioridade esvaziada, morta. Fala mesmo em "ossuário de interioridades putrefatas"45 Os versos baudelairianos fiam alegorias da perda, que a uma vez revelam e derruem a segunda natureza da mercadoria que domina o espaço e o tempo modernos. Mas eles igualmente se atrevem a mostrar as cicatrizes do processo na interioridade humana, com a desconsolada exibição do vazio que a atravessa.

A par com tais problemas surge a premência do suvenir na modernidade, que Benjamin contrapõe à relíquia. Ele é tomado como emblema de uma interioridade esvaziada e de uma experiência morta. O suvenir estaria assim para a vivência como a relíquia para a experiência:

O suvenir [souvenir] é a relíquia secularizada. O suvenir é o suplemento da "vivência". Nele se corporifica a crescente auto-alienação do homem, que

\footnotetext{
42 Idem, p. 134.

43 Idem, p. 135.

44 Idem, p. 146.

${ }^{45}$ LUKÁCS, A teoria do romance, p. 64.
} 
inventariza o seu passado como um passivo morto. No século XIX, a alegoria andou esvaziando o mundo exterior para se sediar no mundo interior. A relíquia provém do cadáver; o suvenir, da experiência já morta que, eufemisticamente, se chama de vivência. ${ }^{46}$

A relíquia teria gênese diversa da mercadoria. Era parte de uma totalidade orgânica, o símbolo de uma ausência, substituto direto, eficaz ou não. Diverso é o caso do suvenir. Sua gênese reside na mercadoria, que se metamorfoseia pela afetividade e recordação. É um fragmento e substituto indireto, e isso porque, em vez de aduzir o que se perdeu, multiplica ao infinito a perda, sem temer que disso nem mesmo a escrita escape. Não é assim o símbolo de uma perda, mas o emblema de partes diversas do que se perdeu, cada uma correspondendo a outras muitas recordações. O emblema de um conhecimento impossível, de uma totalidade indisponível. Contenção da relíquia, dispersão do suvenir.

Como Benjamin já demonstrava em $A$ origem do drama barroco, a figura-chave da alegoria barroca era o cadáver ${ }^{47}$. Agora, ele vê no suvenir a figura-chave da alegoria moderna:

\begin{abstract}
A figura-chave da alegoria antiga é o cadáver. A figura-chave da alegoria mais recente é o suvenir. $O$ suvenir se insere no esquema da metamorfose da mercadoria em um objeto de colecionador. De acordo com a sua temática, as correspondances são as múltiplas infinitas ressonâncias de cada suvenir nos demais, de cada recordação nas outras. "Tenho mais recordações do que se tivesse mil anos." 48
\end{abstract}

O suvenir conhece a passagem de mercadoria a objeto de colecionador, disparando o processo relacional dos objetos uns com os outros ditados pelo ritmo da recordação. Benjamin serve-se mesmo do caro termo baudelairiano correspondance. As diversas correspondências funcionam por força da associação a que impele o suvenir. Seria equivocada a pressuposição de que essas correspondências reconduzem-nos a uma nova totalidade, a uma síntese superior. O plano é mais alegórico que simbólico. Essa alusão de tudo a tudo não tem repouso. Em Baudelaire,

\footnotetext{
${ }^{46}$ BENJAMIN "Parque central", p. 143-4.

${ }^{47}$ BENJAMIN, Origem do drama barroco alemão. Trad. Sergio Paulo Rouanet. São Paulo: Brasiliense, 1984. Tome-se, por exemplo, esta passagem: "Ao passo que no símbolo, com a transfiguração do declínio, o rosto metamorfoseado da natureza se revela fugazmente à luz da salvação, a alegoria mostra ao observador a facies hippocratica da história como protopaisagem petrificada. A história como tudo o que nela desde o início é prematuro, sofrido e malogrado, se exprime num rosto - não, numa caveira." (p. 188)
} 
perdemos a Origem. Eis o que significa a transcendência vazia da sua lírica. O gesto tem a violência da confrontação de toda e qualquer ideologia, haja vista esta nutrir-se justamente do repouso do sentido. Compreende-se, como veremos na seção seguinte, as apreensões de Lukács: em semelhante procedimento não disporíamos de nenhum auxílio para quadrar a experiência artística com as exigências revolucionárias do comunismo europeu. Hoje não é difícil expressar gratidão por essa incompetência da alegoria.

O caráter destrutivo da alegoria teria de confrontar-se com o mito, o que ocorre em Baudelaire, algo que Benjamin não tem dificuldade em ratificar. Em um ensaio de mocidade, já revelava desconfiança com relação ao aparato acrítico e dominador do mito $^{49}$ associado ao poder e ao direito. Com relação a Baudelaire, o mito é confrontado por velar todo um quadro de enfeitiçamento das mercadorias pela projeção de desejos particulare ${ }^{50}$. Alegoria e mito opõem-se: a transitoriedade, temporalidade da renúncia das certezas, que inspira a alegoria, destruiria o plano da estática mítica: "É preciso mostrar na alegoria o antídoto contra o mito. O mito era o cômodo caminho que Baudelaire proibiu a si mesmo." ${ }^{\text {51 }}$ Foi mesmo a alegoria o que impediu que o poeta francês caísse nas teias do mito que tanto o assediavam: "É preciso desenvolver claramente a antítese entre alegoria e mito. Foi graças ao gênio da alegoria que Baudelaire não caiu no precipício do mito que acompanhava constantemente seu caminho."52

Destarte, o caráter destrutivo da alegoria trai um substrato político, pela crise a que impõe o esplendor da mercadoria. Willi Bolle sustenta residir em semelhante gesto crítico e alternativo a reintrodução da alegoria na modernidade, recurso em princípio "extemporâneo" e que se ligaria à necessidade de fazer face à tendência notavelmente desvalorizadora a que nos submete o império da mercadoria:

\footnotetext{
${ }^{48}$ Idem, p. 151.

${ }^{49}$ BENJAMIN, Walter. Documentos de cultura, documentos de barbárie: escritos escolhidos. Org. Wiili Bolle. Trad, Celeste H. M. Ribeiro de Souza et al. São Paulo, Cultrix/Edusp, 1986. P. 171s.

${ }^{50}$ BUCK-MORSS, op. cit., p. 200.

${ }^{51}$ BENJAMIN. "Parque central", p. 140.

${ }^{52}$ BENJAMIN, Passagens. Org, edição brasileira: Willi Bolle, com colabora de Olgária Matos. Trad. do alemão: Irene Aron; trad. do francês: Cleonice Paes B. Mourão. Belo Horizonte: Editora UFMG; São Paulo: Imprensa Oficial do Estado de São Paulo, 2006. J22,5, p. 313.
} 
A razão genérica para a reintrodução da alegoria, conforme já foi explicado, está na possibilidade de fazer contrapeso ao mecanismo moderno da desvalorização, acionado pela moda, a publicidade e 0 fetichismo da mercadoria, com o emblema mais antigo da desvalorização, que é o "esqueleto" ou o "cadáver" ${ }^{53}$

A alegoria moderna desvaloriza o mundo sensível com o emblema da fugacidade que, entre os escritores barrocos, era a caveira. Nesse sentido é afim ao rebaixamento às exigência de novidade recorrentes na moda e publicidade, e que findam por nadificar homens e objetos. No entanto, tal afinidade tem sua contraparte dialética ao jogar na face da mercadoria o espelho da dissolução futura do próprio sistema capitalista - por ser o espelho da fugacidade do próprio sistema que possibilita a dominância da mercadoria.

A alegoria barroca era infensa ao brilho da harmonia cujo fulgor adiante seduziria os românticos. O amálgama de sensibilidade teológica para o problema do mal e do sofrimento, e a desolação social que a época conheceu concitavam a urdir fios em que a fragmentação e a perda eram cruciais. Outrossim, também a harmonia é um pressuposto inadequado para a composição poética segundo Baudelaire. Nada mais equivocado do que afirmá-la numa época de esvaziamento dos homens e dos objetos, sujeitos ao inferno do eterno retorno do mesmo, sob a mal disfarçada face do sempreigual. A harmonia nesse quadro seria apenas a contraparte alegórica de sua própria impossibilidade, recalcada no falso brilho dos símbolos auráticos da publicidade.

\section{Alegoria e vanguarda: o mundo sob a inscrição da perda}

A importância do conceito benjaminiano de alegoria para a compreensão da arte de vanguarda foi bem sublinhada por Lukács. $O$ crítico húngaro dedicou à alegoria e às vanguardas cuidadosa análise, pois se the afiguravam em tudo diversas do que ele defendia: o realismo crítico. Ele intentou com isso demonstrar a insuficiência das expressões artísticas vanguardistas, atacando seu próprio esteio de composição, a

\footnotetext{
${ }^{53}$ BOLLE, Willi. A fisiognomia da metrópole: representação da história em Walter Benjamin. $2^{\mathrm{a}}$. ed. São Paulo, Edusp, 2000. P. 128.
} 
alegoria, conquanto não disfarçasse a admiração, em muitos trechos, por Walter Benjamin $^{54}$.

A vanguarda literária teria promovido certo esvaziamento da concretude do mundo histórico, resultando num desfile de formas vazias e personagens com traços perfeitamente intercambiáveis, dado o descuido com uma caracterização mais precisa. Com isso se constrói uma subjetividade abstrata e anódina para impor qualquer mudança efetiva no status quo reinante sobre o qual aparentemente desfiava tanta lamentação: "La retórica negación de la realidad se basa objetivamente en la incapacidad para dominar los problemas reales decisivos." ${ }^{55} \mathrm{O}$ zelo pelo primado ontológico da solidão humana e do caráter em última instância incógnito de seus atos pertence à mesma ilusão que pretende abstrair os móveis concretos, do ponto de vista histórico-social, da ação humana:

Como se vê, não se trata nem de uma questão que diga respeito a uma ciência particular, nem de um problema de técnica literária, mas de todo um complexo que se enraíza numa concepção do mundo. O essencial, neste caso, é a idéia que se faz do homem, considerado a priori como um ser isolado. ${ }^{56}$

O assomo de importância dado ao aspecto patológico das personagens e a deformação que estrutura os textos são traços recorrentes na literatura de vanguarda, segundo Lukács. Servem ao intento de contrapor às deficiências da realidade efetiva a degradação psíquica e moral, espécie de espelho das relações sociais imersas na frieza e heteronomia. Trata-se, segundo o crítico húngaro, de um esforço vão e falso, um "rousseauísmo pervertido". Após escrever brevemente sobre Pasiphaé, de Henry de Montherlant, em que a heroína alimenta uma paixão "curiosa" por um touro, emblema do retorno às origens mais prístinas da existência humana, antes da corrupção social, Lukács conclui que:

Reencontramos, porém, em Montherlant, tão claramente quanto em Musil, o mesmo caráter atribuído ao patológico - protesto inconsciente, ou melhor, recalcado pela sociedade - o mesmo rousseauísmo pervertido, a mesma

\footnotetext{
${ }^{54}$ LUKÁCS, Georg. Realismo crítico hoje. Trad. Ermínio Rodrigues. Brasília, Coordenada-Editora de Brasília, 1969. P. 75.

${ }^{55}$ LUKÁCS, Georg. Estética: I. la peculiaridad de lo estético. 4. cuestiones preliminares de lo estético. Trad. Manuel Sacristán. Barcelona, Ediciones Grijalbo, 1965. V. 4, p. 471.

${ }^{56}$ LUKÁCS, "Realismo crítico hoje", p. 53.
} 
recusa do social. É esta uma característica geral de toda a literatura de vanguarda. ${ }^{57}$

A literatura de vanguarda parece fazer da perda uma estratégia textual privilegiada. No entanto, especialmente no caso da alegoria, seria equivocado ver nisso adesão a um estado nostálgico invencível, uma saudade edênica paralisante. Aqui, como em outros lugares, o filósofo húngaro não parece ter entendido corretamente o processo. Antes, justamente por jazer vedado o reencontro desse algo perdido é que a escrita assume toda a sua urgência crítica. $O$ fato de o retorno nos ser obstado faz da visada nos liames sócio-históricos do homem o máximo interesse da escritura, mormente em seu teor fragmentário. Apenas resulta inaceitável ser o realismo crítico (de um Thomas Mann, segundo o exemplo amado de Lukács) nossa única ou mesmo melhor alternativa. $\mathrm{O}$ índice do pertencimento social não se revela somente nos vincos explícitos, mas também na ausência, no sujeito isolado que denuncia as deficiências e mesmo a abominação do tecido social. Os traços podem mesmo parecer excessivamente abstratos, mas é que numa sociedade massificada vemos margear a todo instante semelhante desfiguração da concretude do sujeito, erguido a um patamar de notável abstração, a uma vez espúria e banalizadora.

Lukács julga ser o conceito benjaminiano de alegoria uma categoria estética crucial à literatura de vanguarda, e acerta: Benjamin "representa una teoría de la alegoría muy enérgicamente pensada hasta el final, viendo en la alegoría el estilo específico realmente adecuado a la sensibilidad, el pensamiento y la vivencia modernos ${ }^{58}$. A descrição que dela oferece, bem como o diálogo que mantém com Benjamin são esclarecedores, o mesmo não podendo ser dito acerca das reservas que enuncia, já dirigidas à literatura de vanguarda. Há um duplo traço importante que o crítico húngaro sublinha na alegoria: uma transcendência que se define antes por via negativa, na atitude de recusa à imanência; o assesto na ausência de significado interno ao mundo. O caráter negativo de semelhante transcendência careceria, segundo Lukács, de eficácia crítica. É nesse sentido que ele julga de modo inclemente

\footnotetext{
57 Idem, p. 55.

${ }^{58}$ LUKÁCS, Estética, p. 457-8.
} 
a "transcendência vazia" da lírica moderna ${ }^{59}$. Esse processo é denominado "niilismo estético": "nihilismo estético, el cual se ha convertido en fundamento del nuevo tipo de conformación alegórica." 60

São traços característicos de uma concepção de mundo angustiada, desesperançada e que nos desiludiria de qualquer esforço de transformação do mundo estreito da mediocridade burguesa:

\begin{abstract}
A transcendência a que ela [a alegoria] se refere implica, mais ou menos conscientemente, na recusa de toda imanência possível, de todo esforço para dar um sentido ao mundo terreno, para atribuir uma significação interna ao próprio mundo, tanto na vida do homem como na sua realidade efetiva. ${ }^{61}$
\end{abstract}

Cabem aqui pelo menos três objeções:

1. A crítica lukacsiana deixa de observar a tensão dialética que compõe a escritura de vanguarda: se por um lado seu zelo alegórico a conduz a um rebaixamento da imanência, ela o faz precisamente com a exaltação imanente da concretude da escrita. A colocação em primeiro plano da materialidade da escrita assenta no gesto imanente os acenos de uma transcendência que se define negativamente não por ausência de esperança, mas por tê-la em demasia.

2. A ausência de significado interno ao mundo antes revela a premência de responsabilidade que o torpor conformista. Que essa responsabilidade não se traduza em apreensão da Verdade da História é um lembrete contra as reduções totalitárias e intolerantes. A perda pode nos segredar regras práticas de prudência histórica, nas malhas da escrita fragmentária. Os textos rasgados celebram alegoricamente a lembrança de violências passadas, e também gestos esperançosos de textos abertos à espera do diálogo genuíno.

3. A crítica lukacsiana à desmontagem alegórica de significados internos ao mundo, supostamente observáveis na literatura de vanguarda, parece conceder relevo a um nilismo que grassaria suas obras. No entanto, esquece-se de que semelhante niilismo, como o esclareceu Nietzsche, fonte importante para as vanguardas, é bifronte: conhece certamente um momento de desesperação, que o autor de Zaratustra chamou

\footnotetext{
${ }^{59}$ Idem, p. 465. Lukács menciona o trabalho de Hugo Friedrich, A estrutura da lírica moderna, do qual retira alguns comentários, mormente os dedicados à poesia de Arthur Rimbaud.

60 Idem, p. 418.

${ }^{61}$ LUKÁCS, "Realismo crítico hoje", p. 67.
} 
de nilismo passivo. Mas possui também sua face transgressora, inconformada, ávida de mudanças, o niilismo ativo. Se é justo ver na literatura de vanguarda a presença de um espírito niilista, isso se legitimaria com a condição de conceder-lhe os matizes necessários: desesperação angustiada que insinua um sentimento prestes a assumir o compromisso com a mudança.

Benjamin não se dispõe a repetir o gesto idealizante do materialista Lukács, que pretendia ocupar-se com a exemplaridade de traços positivos por meio dos quais se afrontaria o sofrimento no palco da história. Pensando diferentemente, excogitava a maior eficácia da exibição do tormento mesmo que se imiscui no movimento do que chamamos de realidade ${ }^{62}$. É assim que da exibição alegórica das ruínas da modernidade uma outra leitura, emancipadora, se divisaria.

\footnotetext{
${ }^{62}$ Apreciação positiva da construção alegórica na arte de vanguarda foi oferecida, entre outros, por: Bürger, Peter. Teoria da vanguarda. Trad. Ernesto Sampaio. Lisboa, Veja, 1993. p. 117s; Rochlitz, Reiner. O desencantamento da arte: a filosofia de Walter Benjamin. Trad. Maria Elena Ortiz Assumpção. Bauru, EDUSC, 2003. p. 295s.

Rochlitz polemiza com Bürger, quando mostra suas ressalvas quanto a se tomar a alegoria como "modelo" da arte de vanguarda, pois argumenta que o próprio Benjamin resistia a modelos para a arte moderna (p. 299). Trata-se de um debate instigante, mas que foge ao foco do nosso trabalho.
} 


\section{BIBLIOGRAFIA}

ADORNO, Theodor. "Caracterização de Walter Benjamin". In Prismas: crítica cultural e sociedade. Trad. Augustin Wernet e Jorge Mattos Brito de Almeida. São Paulo: Ática, 1998.

BAUDELAIRE, Charles. As flores do mal. Trad. Ivan Junqueira. Rio de Janeiro: Nova Fronteira, 1985. Edição bilíngüe.

BENJAMIN, Walter. "Crítica da violência - crítica do poder". In Documentos de cultura, documentos de barbárie: escritos escolhidos. Org. Wiili Bolle. Trad, Celeste H. M. Ribeiro de Souza et al. São Paulo: Cultrix/Edusp, 1986.

Brasiliense, 1984.

Origem do drama barroco alemão. Trad. Sergio Paulo Rouanet. São Paulo:

.Paris, capital do século XIX". In Sociologia. Trad. Flávio Kothe. São Paulo: Ática, 1991a. (Coleção Grandes Cientistas Sociais). p. 31.

. "Parque central". In Sociologia. Trad. Flávio Kothe. São Paulo: Ática, 1991b. (Coleção Grandes Cientistas Sociais).

Passagens. Org, edição brasileira: Willi Bolle, com colabora de Olgária Matos. Trad. do alemão: Irene Aron; trad. do francês: Cleonice Paes B. Mourão. Belo Horizonte: Editora UFMG; São Paulo: Imprensa Oficial do Estado de São Paulo, 2006.

BERMANN, Marshall. Aventuras no marxismo. Trad. Sonia Moreira. São Paulo: Companhia das Letras, 2001.

BOLLE, Willi. A fisiognomia da metrópole: representação da história em Walter Benjamin. 2a . ed. São Paulo: Edusp, 2000.

BUCK-MORSS, Susan. Dialética do olhar: Walter Benjamin e o projeto das Passagens. Trad. Ana Luiza Andrade. Belo Horizonte: Editora UFMG; Chapecó: Editora Universitária Argos, 2002.

BÜRGER, Peter. Teoria da vanguarda. Trad. Ernesto Sampaio. Lisboa: Veja, 1993.

FRIEDRICH, Hugo. A estrutura da lírica moderna: da metade do século XIX a meados do século XX. Trad. do texto por Marise M. Curioni; trad. das poesias por Dora F. da Silva. São Paulo: Duas Cidades, 1978.

IANNI, Octavio. Dialética e capitalismo: ensaio sobre o pensamento de Marx. $3^{\mathrm{a}}$. ed. Petrópolis: Vozes, 1988.

KOLAKOWSKI, Leszek. Las principales corrientes del marxismo: I. los fundadores. Trad. Jorge Vigil. Madrid: Alianza Editorial, 1978. 
LÖWY, Michel. Romantismo e messianismo: ensaios sobre Lukács e Walter Benjamin. Trad. Myrian Veras Baptista e Magdalena Pizante Baptista. São Paulo: Perspectiva/Edusp, 1990.

LUKÁCS, Georg. História e consciência de classes: estudos sobre a dialética marxista. Trad. Rodnei Nascimento. São Paulo: Martins Fontes, 2003.

Estética: I. la peculiaridad de lo estético. 4. cuestiones preliminares de lo estético. Trad. Manuel Sacristán. Barcelona: Ediciones Grijalbo, 1965. V. 4.

Realismo crítico hoje. Trad. Ermínio Rodrigues. Brasília: Coordenada-Editora de Brasília, 1969.

A teoria do romance: um ensaio histórico-filosófico sobre as formas da grande épica. Trad. José Marcos Mariani de Macedo. São Paulo: Duas Cidades/Ed. 34, 2000. (Coleção Espírito Crítico).

MARX, Karl. O capital: crítica da economia política. Trad. Regis Barbosa e Flávio Kothe. São Paulo: Abril Cultural, 1983. Vol. 1.

MARX, Karl e ENGELS, Friedrich. A ideologia alemã. Trad. José Carlos Bruni e Marco Aurélio Nogueira. $11^{\text {a }}$. ed. São Paulo: Hucitec, 1999.

MERQUIOR, José Guilherme. O marxismo ocidental. Trad. Raul de Sá Barbosa. Rio de Janeiro: Nova Fronteira, 1987.

ROCHLITZ, Reiner. O desencantamento da arte: a filosofia de Walter Benjamin. Trad. Maria Elena Ortiz Assumpção. Bauru: EDUSC, 2003.

ROSDOLSKY, Roman. Gênese e estrutura de 0 capital de Karl Marx. Trad. César Benjamin. Rio de Janeiro: EDUERJ/Contraponto, 2001.

SCHELLING, F. W. J. Filosofia da arte. Trad. Márcio Suzuki. São Paulo: Edusp, 2001. (Clássicos). 